DOI:10.17951/h.2015.59.2.151

\begin{tabular}{lcc}
\hline \multicolumn{3}{c}{ A N N A L E S } \\
UNIVERSITATIS & MARIAE CURIE-SKŁODOWSKA \\
LUBLIN - POLONIA & \\
VOL. XLIX, 2 & SECTIOH H \\
\hline
\end{tabular}

Akademia Leona Koźmińskiego w Warszawie, Katedra Prawa Finansowego i Prawa Podatkowego

\author{
ALICJA POMORSKA \\ e-mail: alpom40@wp.pl
}

\title{
Najnowsze zmiany $w$ konstrukcji podatku dochodowego od osób fizycznych w Polsce
}

The latest changes in the construction of personal income tax in Poland

\begin{abstract}
Słowa kluczowe: podatek dochodowy od osób fizycznych, kwota minimum wolnego od podatku, ulgi prorodzinne w podatku
\end{abstract}

Keywords: personal income tax, income-tax-free threshold, family tax relief measures

\section{Wprowadzenie}

Od wielu już lat w europejskiej doktrynie prawno-finansowej eksponuje się coraz wyraźniej funkcje pozafiskalne podatku dochodowego od osób fizycznych, w tym zwłaszcza jego funkcję redystrybucyjną. Co więcej - docenienie tejże funkcji staje się coraz bardziej powszechne i obecne w ustawodawstwach podatkowych współczesnych, rozwiniętych gospodarczo państw, realizujących zasadę sprawiedliwości społecznej.

Podatek dochodowy od osób fizycznych z uwagi na swój powszechny i bezpośredni charakter jest szczególnie predestynowanym do pełnienia roli istotnego instrumentu realizacji funkcji redystrybucyjnej poprzez niwelowanie istniejących różnic w poziomie dochodów poszczególnych grup społecznych, a także gospodarstw domowych.

W realizacji tejże funkcji szczególnie przydatne i szeroko zresztą wykorzystywane w praktyce są trzy elementy konstrukcyjne podatku, tj.: kwota wolna od podatku, skala progresywna oraz wysokość jej stawek, a także różnego rodzaju stosowane ulgi i zwolnienia podatkowe. Te trzy elementy konstrukcji podatku niestety - jak 
dotąd - nie są w pełni i skutecznie wykorzystywane w celach redystrybucji dochodów podatników w aktualnej konstrukcji polskiego podatku dochodowego od osób fizycznych. Dlatego też zasługują na istotne zmiany.

Duże nadzieje na pożądane zmiany wiązano z przygotowanymi już w 2014 r. dwoma projektami zmian $\mathrm{w}$ tymże podatku, które $\mathrm{w}$ swych założeniach służyć miały istotnemu wzmocnieniu funkcji redystrybucyjnej podatku oraz skuteczniejszej realizacji polityki prorodzinnej rządu.

Poselski projekt zmian [Poselski projekt ustawy..., 2014 r.] niósł ze sobą niezwykle potrzebne i korzystne dla ogółu podatników podwyższenie kwoty wolnej od podatku, natomiast projekt rządowy zawierał potrzebne i oczekiwane - zwłaszcza przez rodziny wielodzietne - korzystne rozwiązania w systemie ulg przyznawanych $\mathrm{z}$ tytułu posiadania dzieci. Niestety, tylko rządowy projekt [Rządowy projekt ustawy..., 2014 r.] uzyskał aprobatę Sejmu i to jego założenia uwzględnia aktualny tekst ustawy z 2014 r. [Dz. U. z 2014 r., poz. 1644]. Natomiast projekt poselski został odrzucony przez Sejm już w pierwszym czytaniu i to głównie z przyczyn natury finansowej. W tenże sposób zakres projektowanych zmian uległ znacznemu ograniczeniu.

Generalnie trzeba jednak przyznać, iż sam wybór do realizacji w pierwszej kolejności zmian w systemie obciążenia podatkiem dochodowym wielodzietnych rodzin z niskim dochodem był w pełni uzasadniony i to nie tylko ich wyjątkowo trudną sytuacją finansową, ale też koniecznością zahamowania niekorzystnych trendów i zjawisk natury demograficznej polskiego społeczeństwa w postaci występującego wyraźnego jego starzenia się oraz równoczesnego, niskiego (1,3\%) wskaźnika dzietności kobiet, a w tym nawet odnotowanego w 2013 r. rekordowo ujemnego przyrostu naturalnego, wynoszącego 0,4 promila [Guza, 2014, s. A5].

\section{Analiza i ocena nowo wprowadzonych zmian w konstrukcji polskiego podatku dochodowego od osób fizycznych}

Przedmiotem artykułu jest analiza i ocena zarówno nowoprzyjętych w konstrukcji podatku rozwiązań, jak też rozwiązań niezaakceptowanych przez Sejm, zawartych W poselskim projekcie zmian. W pierwszej kolejności analizie i ocenie poddane zostaną przyjęte przez Sejm dwa nowe rozwiązania w systemie ulg prorodzinnych, z których będą mogli skorzystać podatnicy już przy rozliczeniu podatku za $2014 \mathrm{r}$.

Pierwsze rozwiązanie, wręcz nowatorskie $\mathrm{w}$ dotychczasowej regulacji prawnej konstrukcji podatku, ma zapewnić podatnikom - zwłaszcza wielodzietnym rodzinom z niskimi dochodami - możliwość odliczenia od podatku pełnej kwoty przysługujących im ulg z tytułu posiadania i wychowywania dzieci poprzez wprowadzenie instytucji dopłaty z budżetu brakującej kwoty do pełnego odliczenia tychże ulg. Dopłata ta, stanowiąca różnicę pomiędzy kwotą przysługujących podatnikowi ulg na dzieci a kwotą odliczoną w zeznaniu podatkowym, traktowana będzie na równi z nadpłatą podatku, która wymaga zwrotu podatnikowi. 
Dotychczas rodziny wielodzietne z niskimi dochodami, a w konsekwencji obciążone niskim podatkiem dochodowym, nie były w stanie dokonać pełnego odliczenia od kwoty należnego od nich podatku przysługujących im ulg, tracąc w ten sposób część korzyści finansowych. Oznaczało to, iż zamierzony i zgodny z zasadą sprawiedliwości społecznej cel wsparcia finansowego najbiedniejszych, wielodzietnych rodzin w praktyce nie mógł być osiągnięty, a to z powodu wadliwie skonstruowanego mechanizmu stosowania ulg. Jest sprawą wręcz zdumiewającą, a przy tym wielce naganną, iż twórcy powyższych zasad przyznawania ulg nie przewidzieli takich negatywnych skutków ich działania czy też nie mieli rozeznania w realnej sytuacji dochodowej większości rodzin wielodzietnych w Polsce. Jak podaje Ł. Guza [2014, s. A5], przy rozliczeniu podatku za rok $2013 \mathrm{z}$ tychże ulg w pełni skorzystało tylko $76 \%$ rodzin z jednym dzieckiem, $68 \%$ z dwojgiem dzieci i już tylko $31 \%$ rodzin wychowujących troje lub więcej dzieci. Dopiero wprowadzenie dopłat do brakującej kwoty odliczenia zapewni możliwość pełnego skorzystania z przysługujących im ulg.

Warto także zwrócić uwagę na wprowadzone ograniczenie wysokości dopłaty z budżetu do łącznej kwoty opłaconych przez podatnika składek na ubezpieczenie społeczne i zdrowotne. Rozwiązanie powyższe nie powinno bowiem zniechęcać podatników do podejmowania pracy, a wprost przeciwnie: winno promować ich legalne zatrudnienie i skutecznie pomóc w walce z szarą strefą [Skwirowski, 2015, s. 24].

Drugim, równie korzystnym, nowym rozwiązaniem jest znaczące podwyższenie - o 20\% dotychczasowych kwot ulg przyznawanych na trzecie, czwarte oraz każde kolejne dziecko w rodzinie. Podwyżka ta spowoduje, iż ulga na trzecie dziecko wzrośnie z dotychczasowej kwoty 1668,12 zł do kwoty 2400 zł rocznie, a ulga na czwarte i kolejne dziecko w rodzinie z obecnej kwoty 2224,08 zł do 2700 zł rocznie. Szacowane przez Ministerstwo Finansów skutki finansowe wprowadzonych zmian określa się na 1 mld 100 mln złotych w 2015 r.

Wielka szkoda, iż odrzucony został przez Sejm poselski projekt zmian w konstrukcji podatku, zmierzający do podwyższenia kwoty wolnej od podatku. Aktualna kwota minimum wolnego od podatku w wysokości $3091 \mathrm{zł}$ rocznie jest rażąco niska - co więcej: nawet ponad dwukrotnie niższa od wielkości dochodu ustalonej na poziomie 6504 zł rocznie dla osoby samotnej, a dla osoby żyjącej w rodzinie 5472 zł. Prowadzi to wręcz do paradoksalnej sytuacji, jako że osoby z tak niskim rocznym dochodem mają pełne prawo do zasiłków i dodatków socjalnych, ale równocześnie muszą płacić podatek. Stąd też nie budzi zdziwienia fakt, iż ta aktualna kwota minimum wolnego od podatku stała się przedmiotem skargi rzeczniczki praw obywatelskich skierowanej do Trybunału Konstytucyjnego jako sprzecznej z konstytucyjną zasadą sprawiedliwości społecznej [Gomułowicz, 2001].

Generalnie rzecz ujmując, wysokość minimum wolnego od podatku winna być kształtowana przez kwotę minimum egzystencji, którą ustala w Polsce Instytut Pracy i Spraw Socjalnych. Zgodnie z definicją przyjętą przez tenże Instytut kwota minimum egzystencji ,wyznacza poziom zaspokojenia potrzeb konsumpcyjnych, poniżej którego występuje biologiczne zagrożenie życia i rozwoju psychofizycznego 
człowieka". Wysokość tak pojętego minimum egzystencji dla jednoosobowego gospodarstwa pracowniczego ustalono na poziomie 521,11 zł miesięcznie, co w skali roku daje kwotę 6253,12 zł. Taką właśnie wielkość minimum wolnego od podatku proponował projekt poselski, który uznał dotychczasowe regulacje w zakresie wysokości minimum wolnego od podatku jako „w najwyższym stopniu niemoralne i rażąco sprzeczne z elementarnym poczuciem sprawiedliwości społecznej, które dotąd pozwalały państwu na pobieranie podatku od podatników z dochodem tak niskim, że nie pokrywał on niezbędnych wydatków na żywność i opłat za mieszkanie" [Poselski projekt ustawy..., 2014].

Warto przy tym zwrócić uwagę, iż ta projektowana - jako dwukrotnie wyższa od obecnej - kwota minimum wolnego od podatku, stanowiąca dwunastokrotność kwoty miesięcznego minimum egzystencji, jest nadal niewystarczająco wysoka, jako że zwalnia ona od opodatkowania dochód zaledwie w wysokości około 17 zł dziennie. Ta proponowana, mimo że zwiększona kwota minimum wolnego od podatku jawi się w dalszym ciągu jako rażąco niska, zwłaszcza na tle wielkości minimum wolnego od podatku przyjętego w wielu państwach Unii Europejskiej, w których w przeliczeniu na polskie złote wynosi ona np. w Grecji około 20 tysięcy, w Niemczech - 30 tysięcy, w Wielkiej Brytanii - 50 tysięcy [Skwirowski, 2014, s. 24]. Nawet uwzględniając fakt znacznie wyższych płac i dochodów z innych źródeł, które osiągają podatnicy w tych państwach, są to kwoty nieporównywalne z wysokością polskiego minimum wolnego od podatku.

Krytycznie ocenić należy również fakt zaprzestania, począwszy od 2008 r., waloryzacji kwoty wolnej od podatku i jej zamrożenie, mimo iż wskaźnik inflacji w okresie od marca 2008 do marca 2014 r. wyniósł 17,3\%. Fakt ten jest czynnikiem znacznego poszerzenia się sfery ubóstwa w naszym kraju.

Głównym argumentem przeciwstawiającym się projektowanej podwyżce kwoty wolnej od podatku, zgłaszanym zarówno przez sekretarza stanu w Ministerstwie Finansów, jak też przez posłów koalicji [sprawozdanie stenograficzne z posiedzenia Sejmu] była obawa destabilizacji systemu finansów publicznych, którą mogłyby wywołać skutki finansowe wprowadzenia powyższej zmiany w postaci szacowanego przez Ministerstwo Finansów zmniejszenia wpływów do systemu budżetowego na kwotę o około 11,9 mld zł. Taki ubytek dochodu nie byłby do zaakceptowania, a to głównie z dwóch powodów - koniecznego zachowania równowagi budżetowej, która jest wartością konstytucyjnie chronioną, jak też szczególnie niekorzystną sytuacją budżetu państwa objętego unijną procedurą nadmiernego deficytu. Wprawdzie procedura ta jest obecnie czasowo zawieszona, ale pod warunkiem i za cenę wprowadzenia w Wieloletnim Planie Finansowym Państwa na lata 2014-2017 zamrożenia kwoty wolnej od podatku, a także wysokości progów dochodowych oraz kwoty zwolnień podatkowych. Oznacza to, iż w takiej sytuacji poselska propozycja podwyższenia kwoty wolnej od podatku niejako już „,z góry” była skazana na niepowodzenie. Ta odroczona w czasie realizacja niezwykle pożądanego i oczekiwanego przez ogół podatników podwyższenia kwoty wolnej od podatku winna skłonić już teraz rząd 
do podjęcia intensywnych prac nad przygotowaniem generalnej koncepcji reformy poziomu jednego $\mathrm{z}$ najważniejszych instrumentów realizacji funkcji redystrybucyjnej podatku, którą stanowi kwota wolna od podatku.

\section{Zakończenie}

Zaprezentowane wyżej główne kierunki zmian wprowadzonych w systemie obciążenia dochodów osób fizycznych, korzystne dla podatników mimo swego wycinkowego zakresu, gdyż ograniczonego jedynie do reformy systemu ulg prorodzinnych, uznać należy za pożądane i oczekiwane przez podatników - stąd też zasługujące na pozytywną ocenę, chociaż wielce spóźnione, niewystarczające i zbyt wąskie. Dlatego traktować je należy jako spóźnioną i niewystarczającą reakcję rządu na wady i słabości aktualnej regulacji podatku dochodowego od osób fizycznych.

Sam zakres reformy dotychczasowych regulacji jest bardzo wąski, jako że dotyczy tylko jednego elementu technicznego konstrukcji podatku, tj. zakresu i wysokości przysługujących ulg na dzieci, zwłaszcza dla rodzin wielodzietnych. Ten wycinkowy charakter dokonanych zmian trudno uznać za oczekiwaną i pożądaną społecznie głębszą, kompleksową reformę podatku. Stanowią one raczej kolejną zmianę w całym nieprzerwanym ciągu już ponad 200 zmian wprowadzonych w konstrukcji podatku dochodowego od osób fizycznych [Ofiarski, 2007].

Mimo niepełnego zakresu projektowanych zmian na pozytywną ocenę zasługuje sam wybór do reformowania w pierwszej kolejności najistotniejszych dla podatników, a przy tym wadliwych i sprzecznych z zasadą sprawiedliwości podatkowej uregulowań w zakresie systemu i zasad przyznawania ulg prorodzinnych $\mathrm{z}$ tytułu posiadania i wychowywania dzieci. Sądzić należy, że podjęte próby reformy uregulowań tak istotnego dla ogółu społeczeństwa będą nadal kontynuowane.

Dla skuteczniejszej realizacji funkcji redystrybucyjnej podatku dochodowego od osób fizycznych w Polsce konieczne wydają się ponadto zmiany polegające na szerszym wykorzystaniu w tymże celu skali progresywnej oraz wysokości jej stawek. Istniejąca społeczna potrzeba wyrównywania szans życiowych poszczególnych grup obywateli poprzez niedopuszczenie do nadmiernych ich rozpiętości dochodowych i majątkowych powoduje, iż nie jest bynajmniej rzeczą przypadku, że większość cywilizowanych, współczesnych państw świata stosuje już od prawie stu lat progresję podatkową jako instrument korygowania rynkowego podziału dochodu w celu eliminowania nadmiernie zróżnicowanych dochodów i majątków [Wach, 2006].

Występujące obecnie w polskim podatku dochodowym zaledwie dwa progi dochodowe, jak też przyjęcie kwoty 85528 zł jako kryterium ich rozróżnienia, a także dwóch stawek w podatku w wysokości 18\% i 32\% trudno uznać za wystarczające do zniwelowania tak znacznej rozpiętości dochodowej podatników [Krajewska, 2012]. Oba progi dochodowe są nazbyt pojemne kwotowo, jako że pierwszy próg obejmuje dochody w wysokości do 85528 zł, a drugi dochody przekraczające tę 
kwotę, co już niejako automatycznie przekreśla możliwość skutecznego niwelowania przez podatek istniejącego w społeczeństwie i ciągle pogłębiającego się procesu jego rozwarstwiania dochodowego. Taką samą bowiem 18-procentową stawką obciążone są niskie dochody pochodzące $\mathrm{z}$ minimalnych i przeciętnych płac oraz emerytur i rent, jak też - wysokie dochody w granicach do 85528 zł (czyli 7000 miesięcznie). Skutki finansowe tak niesprawiedliwego rozłożenia ciężaru podatkowego, odczuwalne przez obydwie grupy podatników, są głęboko zróżnicowane; sytuacja ta nie wymaga komentarza. Stąd też można zaproponować wprowadzenie nowego, trzeciego progu, który obejmowałby dochody roczne w wysokości do 40-50 000, szacowane jako dwunastokrotność kwoty przeciętnego wynagrodzenia miesięcznego w gospodarce narodowej, wynoszącego 3 300-3 500 zł i objęcie ich najniższą stawką na poziomie $9 \%-10 \%$. Proponowane rozwiązanie przyniosłoby zapewne w efekcie bardziej sprawiedliwe niż dotąd rozłożenie ciężaru dochodowego na poszczególne grupy społeczne. $\mathrm{W}$ dalszej perspektywie - jeśli pozwoliłyby na to możliwości finansowe budżetu - można by proponować wprowadzenie czwartego progu dochodowego, obejmującego dochody roczne w granicach do 120000 i objęcie ich stawką w wysokości ok. $23 \%-25 \%$ oraz pozostawienie nadal dotychczasowej 32-procentowej stawki obciążającej dochody powyżej 120000 . Z uwagi na fakt czasowego zamrożenia wysokości progów dochodowych realne możliwości ich zamiany będą możliwe dopiero po $2017 \mathrm{r}$.

Aktualnie w tym pierwszym progu dochodowym mieszczą się dochody ponad $90 \%$ ogółu podatników. Oznacza to, iż w praktyce mamy do czynienia z podatkiem liniowym, absolutnie nieskutecznym w roli instrumentu redystrybucji dochodów.

Jak słusznie podkreśla się w doktrynie, iż [Kołodko, 2008, s. 23] ,podatek liniowy jako element doktryny liberalnej prowadzi do obniżania podatku wąskiej grupie beneficjentów i przerzucania kosztów tejże operacji na grupy o niższych dochodach (cel rzeczywisty), podczas gdy głosi się czy raczej w tym przypadku kłamie, że chodzi tu o stworzenie lepszych przesłanek dla formowania się kapitału i inwestowania (cel deklarowany)".

Prezentowane w artykule wady i słabości aktualnej konstrukcji podatku, w niewielkim tylko zakresie wyeliminowane przez wprowadzone od 2015 r. zmiany w systemie ulg prorodzinnych, są możliwe do usunięcia tylko poprzez generalną, systemową reformę podatku, której zakres i kierunki zdeterminować mogą nieodzowne zmiany w systemie wydatków publicznych. Oznacza to potrzebę jak najszybszego podjęcia prac nad przygotowaniem generalnej, kompleksowej reformy całego systemu finansów publicznych. 


\section{Bibliografia}

1. Gomułowicz A. (2001), Zasada sprawiedliwości podatkowej, Wyd. Dom Wydawniczy ABC, Warszawa.

2. Guza Ł., Rodzić za wszelka cenę, „Dziennik Gazeta Prawna” z 17-19.10.2014 r., nr 202, s. A5.

3. Kołodko G. (2008), Wędrujący świat, Wyd. Prószyński i S-ka, Warszawa, s. 23.

4. Krajewska A. (2012), Podatki w Unii Europejskiej, PWE, Warszawa.

5. Ofiarski Z. (2007), Niestabilność reguł opodatkowania dochodów osób fizycznych w Polsce, [w:] J. Głuchowski, A Pomorska, J. Szołno-Koguc (red.), Podatkowe i niepodatkowe źródta finansowania zadań publicznych, Wyd. KUL.

6. Poselski projekt ustawy o zmianie ustawy o podatku dochodowym od osób fizycznych (druk sejmowy nr 2414) rozpatrywany na posiedzeniu Sejmu RP w dniu 26.06.2014 r., zob. sprawozdanie stenograficzne Sejmu RP z 70. posiedzenia, Warszawa 2014, s. 285-295.

7. Rządowy projekt ustawy o zmianie ustawy o podatku dochodowym od osób fizycznych oraz niektórych innych ustaw (druk sejmowy 2, nr 2781) rozpatrywany na 77. posiedzeniu Sejmu RP w dniu 9.10.2014 r.; zob. sprawozdanie stenograficzne z 77. posiedzenia Sejmu RP, Warszawa 2014, s. 181-191.

8. Skwirowski P., I znów większa ulga na dzieci, „Gazeta Wyborcza” z dnia 9.02.2015 r., s. 12.

9. Skwirowski P., Za biedni na podatek, „Gazeta Wyborcza” z 8.10.2014, s. 24.

10. Ustawa $z$ dnia 23.10.2014 r. o zmianie ustawy o podatku dochodowym od osób fizycznych oraz niektórych innych ustaw, która weszła w życie z dniem 1 stycznia 2005 Dz .U. z 2014 r., poz. 1644.

11. Wach K. (2006), Systemy podatkowe w krajach Unii Europejskiej, Wyd. Oficyna Ekonomiczna, Kraków.

\section{The latest changes in the construction of personal income tax in Poland}

The subject of the paper is an analysis and evaluation of new laws regarding personal income tax implemented from the $1^{\text {st }}$ January 2015 as well as proposals rejected by the Polish Parliament including reasons for the rejection. Due to that, the expected range of change was significantly narrowed, focusing on family tax relief measures only that can be used for 2014 tax settlements. The main change will affect only large families. Therefore, it is not possible to consider this expected reform of the whole personal income tax law, that has already been partially modified over 200 times. The introduced changes are indeed necessary and beneficial for the society, however, they were introduced too late. It was significantly unfair that families with low income and a lot of children were not allowed to benefit form family tax relief for so long. The problem with the personal tax law - too small tax-free threshold still remains in place and in practice it means taxing income necessary for biological survival of a taxpayer.

Projekt jest realizowany w ramach przyznanego grantu przez Narodowe Centrum Nauki decyzją numer DEC-2011/03/B/HS5/02545]. 